\title{
PERSONAL SELLING IN MARKETING
}

\author{
Ioana Olariu \\ „Vasile Alecsandri” University of Bacău, Faculty of Economic Sciences \\ ioana_barin_olariu@yahoo.com
}

\begin{abstract}
Personal selling is a major element in the marketing communication program of a business firm. This article describes in a theoretical way the scope and significance of personal selling in marketing, it outlines the stages of the selling process. Personal selling is the most effective marketing communication tool because it allows salespeople to adapt their presentation to each potential or current client. They use their knowledge of the customer's buying process to choose effective sales strategies. An effective sales presentation is usually the most important element of a sales job. Most well-managed companies want their salespeople to go through the following sequence in making a presentation: locating and qualifying prospects, a preapproach, the presentation itself, closing the sale and follow-up. Finding the best prospects may be the key step in this sequence, but the close may be the hardest part.
\end{abstract}

\section{Keywords}

selling; presentation; follow-up; communication; evaluation

\section{JEL Classification}

M41

\section{Introduction}

Personal selling is direct person-to-person communication (either face to face or by phone) from a seller to a buyer, for the purpose of making a sale. There can be one or more sellers or buyers in a personal selling process. The heart of the personal selling program is the sales presentation. In one sense, there are many different ways to go about making a sale, since every salesperson will approach this objective in his or her own unique manner. On the other hand, after many decades of experience with sales force management, modern corporations have found that sales presentations are usually most effective when salespeople go through a procedure or process consisting of several steps (prospecting, pre-approach, presentation, the close, and follow-up). There are many different kinds of selling jobs. Not all personal selling will go through all these steps in making a sale. The major advantage of the sales process is to focus attention on the fact that it is not enough to simply locate some prospect and deliver an enthusiastic sales pitch. This is the old-fashioned approach to selling. Sales managers in today's modern corporations know the importance of locating the very best prospects and of preparing carefully in advance before delivering a sales pitch. This is particularly true for the creative and persuasive types of selling usually required for the more expensive products and services. Personal selling is the tool of interpersonal relationships within the promotional mix. This implies a two-way communication between sales personal and individual customers.

Personal selling may be more effective than advertising in more complex situations. Sales employees can ask their customers more detail to learn more about their problems, and then adjust marketing offer and its presentation to match the specific needs of each client. The role of personal selling varies from one firm to another. 
Sales process consists of several stages that the employees have to master perfectly. These action steps focus on a specific objective: to attract new customers and solicit orders from them. However, most sales employees spend most of their working time striving to retain existing customers and build long-term relationships with customers.

\section{Finding the best prospects}

It may be the case that the most important part of the entire selling process is simply locating the most promising prospects. Even an excellent sales presentation will fail when it is delivered to a person or a company that has no real need for the product or service, cannot afford to buy it, or is very satisfied with its present long-term supplier. A successful sales presentation always starts with locating prospects who have a clear need for the product or service, have adequate financial resources to pay, would buy a large enough quantity to result in a profitable sale and have the authority to make a decision or a strong recommendation.

The process of reviewing all these criteria for each prospect is known as qualifying the prospect. If any one of these elements is missing, it is normally not worth the salesperson's time to get an appointment and deliver a sales pitch. There are many sources for locating good prospects. Referrals are often among the best sources for qualified leads. These referrals can come from present satisfied customers, from other business contacts, or from social friends. Most of these people are willing to give good referrals, because they know the salesperson personally. Also, they usually know some useful information about the prospect. Other sources for good referrals include dealers and suppliers.

Sometimes a great deal of help can be secured from within the company. Sales managers have usually a great deal of experience with the marketplace, and they can often suggest where good leads can be found. Also, company files can sometimes give data about previous customers that might be useful for another sales call. The first step in completing the sales process is prospection - identifying potential qualified customers, namely those potential buyers that are compatible with the company's offer. The approach of potential clients is crucial to the success of sales. Prospecting is the stage of the sales process, where the sales employee identifies qualified potential customers. Often, sales employee must address many potential buyers, just to get a few transactions. Even if the company provides them tracks prospecting, sales employees must know how to find them alone.

Sales employees must also know how to preselect or to qualify the potential buyers. They may be qualified by studying several types of information: financial capacity, volume of business, special needs, location and possibilities of increasing turnover.

\section{The pre-approach}

Once a good prospect is identified, inexperienced salespeople are usually very anxious to set up an early appointment and deliver their best sales pitch. But experienced salespeople know how important it is to set the stage by learning as much as possible about the prospective customer first. This is called pre-approach. It is based on the principle of the marketing concept that stresses customer orientation. In general, the more a salesperson knows about the prospect, the better are the chances of making a sale.

The salesperson should attempt to get advance information about such points as how big is the company, what is its financial position and credit rating, what special needs or problems does it have, how might the company's products or services satisfy these special needs, who will get involved in making the buying decision, what type of 
motivation or appeal is most likely to be effective, and what are the buyers personal characteristics and outside interests? Some of this information is available from published secondary sources; other parts might be obtained by telephone calls to business acquaintances or other suppliers to the company.

Before proceeding to approach a potential customer, sales employee must find out as much information about the organization and on those in charge of procurement within the organization (characteristics of their styles and buying). Sales employee can obtain this information from several sources: standard reports, published or online, about the organization's work, discussions with friends and acquaintances and others. Further, sales employee must set the objectives of the visit, which can be qualification of potential client, obtain information or even place a sale. Another task is to choose the best method of approach, which can be personal visit, a telephone conversation or a letter.

Optimal scheduling approach should be carefully considered, because many potential customers are busy during certain periods of time. Sales representative must prepare well an overall sales strategy for the potential client. Therefore, preparation approach is the stage in the sales process where the sales employee gathers information about a potential customer prior to the sale visit.

\section{The approach}

Establish a meeting with the potential client can be difficult, even harrowing for inexperienced salesperson. Although the sale should not rely solely on the application of processes, this requires certain ability for the agent to reach the most appropriate people to receive and understand the message conveyed. What matters to creating a long term relationship with the customer relies on how an agent acts. The request for a meeting is the most important process to establish a working relationship, but letters of presentation and references data by third parties may also have a crucial role. For the transaction to take place, the agent must know how to create a relationship of communion with the client, using what it has in common with him and his own experience. If sales are higher or products are new, so the risk is higher for the customer, it is vital for staff to appear credible.

Companies known to have a certain advantage in this phase, so that agencies related to lesser-known companies must do twice as much effort to overcome fears buyer. In approach step, sales employee should know how to present themselves before the prospective buyer and proceeds under auspicious relationship with it. At this stage the utmost importance in terms of sales outside the employee's phrases with this open discussion and comments on the words of the interlocutor. Opening the discussion must be done with positive phrases, such as to gain customer goodwill from the outset. Then they can follow some well-chosen questions to learn more about customer needs, material or displaying a sample presentation times, to attract the attention and curiosity of the buyer. As in all other phases of the sale, it is crucial that the sales employee listen carefully to what the customer says.

The approach is the stage of the sales process where sales employee gets acquainted with the customer first.

\section{The presentation}

On the basis of all the above information, the salesperson can develop a sales presentation that shows a good understanding of the prospect's needs. It can also show how the company's products can answer those needs better than competitors' products. When the salesperson arrives to deliver the pitch, it is important to be well dressed and to start off right. The early moments of a presentation are extremely 
important. The salesperson must have an interesting opening statement and should move quickly to the main points of the presentation. It is important to remember that most buyers are very busy people, and they do not want to wait while the salesperson gets his or her act together. Often, a lengthy written proposal is required also, which can be studied by the prospect after the presentation. Many sales presentations follow the AIDA approach: attention, interest, desire and action. The opening statement should contain a grabber to get the attention of the buyer. This is followed by a discussion of the product or service characteristics, to provide the information needed by the buyer to develop interest in the product. Desire can be generated by showing exactly how the product can solve problems, reduce costs, reduce maintenance needs, or provide other benefits. Action is generated by getting the buyer's signature on a contract or by getting a clear understanding that a sale has taken place. What distinguishes good salespeople is the skill to ask questions. However, agencies often attach much importance to neglect oral presentations and business proposals are made in writing, all prices or tracing letters, which technically can be considered also as part of the presentation.

It is essential that agencies to ensure that they have correctly identified all the buyer needs, the solution offered and that, where possible, even surpassed these expectations, rather than be limited to meet them. Moreover, when there are the right conditions for use visual aids, it can make the buyer to give more credit to the salesperson, product or his company. Agencies with more experience deemed prefabricated presentations, templates are much less important than the carefully structured and tailored to each client. So far, the seller has listened, understood customer needs, trying to figure out what kind of personality is, what is more sensitive, how it can be tackled. Hence, he chose a strategy, the ones prepared before, or has built on the spot, new one. Now is the time to implement it, to prove that the product meets the requirements of its client and convince him to buy. In the introductory phase of the sales process, sales employee tells the buyer "the story of" the product, showing them what benefits it can bring and how it can solve their problems.

The current understanding regarding the practice of marketing is to a much greater extent compatible with the view that the main quality of sales employee is to solve the client's problems, and less talent of delight buyer with nice words or persuade through a pushy sales effort. Buyers today want solutions to their problems, not friendly smiles; wants results, not extravagant praise. They want employees to listen to their sales requirements, to understand their needs and respond to them with appropriate products and services. This approach focuses on meeting the needs of sales requires the employee to have good listening skills and problem solving.

Therefore, the presentation stage of the sales process is when the employee tells the buyer "the story of the product", highlighting its advantages for the customer.

\section{Countering objections}

The buyer will try to shirk or to raise objections to the commercial presentation and must understand that this is the human nature. Again, experienced salespeople will say that the objections should be regarded as being welcomed, because they confirm the interest of the buyer on the product or service, providing questions which are expressed such as a disclose of the real customer needs. Top agents know how to distinguish between different types of objections. Some are nothing but questions the client asks for clarification and they are always welcome. There are also expressing concerns and real objections. Agencies must listen carefully to questions, to ensure that both parties understand better what the real problems are and agree with clients a 
way to solve them. Attention to these questions increases confidence in agent and lays the foundation for future interactions with him.

Objections are a natural customer defense reflex. Most times, the act of selling is perceived by the customer as a confrontation of conflicting interests, and the objections are its most powerful weapons.

Beginners sellers are afraid of objections, while experienced consider them true incentives, data sources, signals from customers that allow them to focus their arguments in the right direction; on the contrary they fear most of silent clients, impenetrable ones. Customers will almost always have objections during the presentation, when they are asked to launch a command. The problem may have been real or just psychological and, in many cases, objections will not be formulated as such, but will remain unspoken.

At the stage of overcoming objections, sales employee should apply a positive approach to bring out unspoken objections, to ask the buyer to clarify any objections, to see these objections as best deals to provide more information and transform them into buying reasons. All sales professionals need specialized training to acquire good skills for resolving objections.

Overcoming objections is the stage in the sales process where the sales employee detects, clarifies and resolves the objections raised by the customer in respect of purchases.

\section{Closing the sale}

For most salespeople, the most difficult AIDA stage is "action", usually referred to as the close. All the effort and preparation come down to this one moment. If the salesperson asks for the signature or agreement and the buyer does not respond, there is a terrible sense of failure or defeat. In order to avoid the risk of asking for the order and getting a refusal, some salespeople will continue talking about the product's merits or about the customer's needs. This is often referred to as talking the sale to death. One strategy that has helped many salespeople is called the assumptive close. By assuming the sale is already made, the salesperson can more easily avoid a direct refusal that might come from asking for the order. This approach also helps to close the presentation on a very positive note. The salesperson has to face a goal and achieve it because it is absolutely necessary for the continuation and development of economic relations. In some cases, agencies offer customers additional features and benefits which do not need, losing business because of this, because they didn't ask them to take a concrete decision.

The effective dosage of efforts means jointly agreeing the objectives pursued either side that can carry on that relationship to new activities. After successfully overcome the objections raised by the potential customer, sales employee will now try to conclude the sale. Sales professionals must know how to recognize the signs gestures, comments and questions - which signals show that the potential customer is ready to make an order. Salesperson has several techniques on closing the sale: may request an order, may summarize the main points of the agreement, may offer to help the buyer in writing the order, and may ask him if what model does he want or can determine that if he doesn't order at the time, the customer will lose out. Sales representative can offer the buyer specific reasons for closing the sale, such as lower prices or additional products delivered for free.

Therefore, the conclusion is the stage of the sales process where the sales employee asks the customer to make an order. 


\section{Follow-up}

After a successful close, there is sometimes still a great deal of work to be done. Delivery dates and locations must be decided upon. Sometimes the customer will ask for minor modifications in the product or service, to suit his or her own company's particular needs. These modifications must be worked out with the designers or production people of the salesperson's company. If a new piece of equipment is being delivered, the customer's own employees must be trained to operate it properly and safely. The salesperson is responsible for seeing that all of these and other details are worked out smoothly and quickly. Even after delivery has been accomplished, the salesperson will stay in close touch with the new customer. For a customer-oriented activity, it is very important to know what happens after the sale. Most buyers are unhappy when promises are not fulfilled and the sales agent is not acting as he told would do. In the current environment, such an omission is fatal for how the agency intends to develop relationships and ability to comply with everything promised, even to make an extra effort to delight the customer; this is the essence of what it means to do business.

The last stage of the sales process - returning later or post-sales - is necessary if the employee wants to ensure customer satisfaction and repeat orders in the future. Immediately after closing, sales employee must complete the information given to the customer with details about the delivery time, conditions of purchase and other issues. Then he must plan customer return visit after receiving the initial order, to ensure that they fulfill all the promises in terms of installation, training and service. That visit will reveal any problems in the meantime, will convince the sincere interest of the buyer and salesperson will diminish any concern arising after completion of the sale. Therefore, the return post-sale is the last stage of the sales process, the sales employee visits the customer again, to ensure that he is satisfied and will continue to buy in the future.

\section{Conclusions}

By its nature, any sale is a single act. However, synthesizing the experience clearly shows that major vendors all have a common structure and sales that travel a rational scheme, the same irrespective of who, what and who sells. This consistency comes from the fact that a sale is first an interpersonal act, between the selling and the buying and, only then, a relationship between two companies; or, from this point of view, people are the same.

General scheme of selling is: researching the market; prospecting (defining and locating potential customers), identification (finding names and addresses) and contacting them, usually by telephone to obtain an appointment; meeting preparation: gathering information about the interlocutor, choose overall strategy, preparation of documentation; meeting customer at his premises or at the vendor; evaluation part, verification of information: decision-making power, financial resources; discovering customer needs: to study its problems, their reformulation favorable terms for the seller; presentation and demonstration; answering objections; summaries of the agreements reached and trying to get a commitment from the client; price discussion; customer purchase decision; negotiation terms of the sale; completion (signing the contract); monitoring and evaluation results, conclusions; resolve customer complaints.

This order of the phases of the sale is almost always respected, even if it skips one or more phases. Vendors are beginning to intervene somewhere between prospecting and meeting preparation, time depending on type of company or the size of its strategies 
etc. In general, the company is larger and more rigorously organized, the less they participate in exploration itself.

\section{References}

Alessandra, T., Wexler, P., Barrera, R. (1997), Nonmanipulative selling, Englewood Cliffs, N.J.: Prentice Hall;

Blythe, J. (2005), Managementul vânzărilor şi al clienţilor cheie, Editura Codecs, București;

Butunoiu, G. (1998), Tehnici de vânzare - curs pentru agenţii de vânzări, Editura All, Bucureşti;

Cole, G.H., Miner, M. (2002), Handling sales objections, National Public Accountant, vol. 47, no. 5, pp. 24-26;

Donaldson, B. (2001), Managementul vânzărilor - teorie şi practică, Editura Codecs, Bucureşti;

Doney, P.M., Cannon, J.P. (April 1997), An examination of the nature of trust in buyer-seller relationships, Journal of Marketing, pp. 35-51;

Futrell, C.M. (2005), ABC's of relationship selling through service, Burr Ridge, IL: Irwin, pp. 418;

Holmlund, M. (2004), Analayzing business relationships and distinguishing different interaction levels, Industrial Marketing Management, vol. 33, pp. 279-87;

Hopkins, T., (1994), How to master the Art of Selling, New York: Warner Books, pp. 191;

Leek, S., Naude, P., Turnbull, W. (2003), Interactions, relationships, and networks in a changing world, Industrial Marketing Management, vol. 32, pp. 87-90;

Natenberg, T. (2004), Referrals: your key to sales success, Selling, pp. 9;

Pierce, H. (2004), Persuasive proposals and presentations: 24 lessons for writing winners, McGraw-Hill, New York;

Proctors, Ph. (Septembrie 2000), A Well-Bread Sale, Selling Power, pp. 20;

Radick, M. (August 1993), Training salespeople to get success on their side, Sales \& Marketing Management;

Robertson, K. (October 2004), Creating a powerful sales presentation, Selling, pp. 12 ;

Schrage, M. (February 2004), Are customers selling for you?, Sales and Marketing Management, pp. 22;

Sparks, J.R., Areni, C.S., (2002), The effects of sales presentation quality and initial perceptions on persuasion: a multiple role perspective, Journal of Business Research, vol. 55, no. 6, pp. 517-28;

Stevens, Ch.; Macintosh, (2002-2003), Personality and Attractiveness of Activities within Sales Jobs, Journal of Personal Selling and Sales Management, no. 23;

Wagner, J.A., Klein, N.M., Keith, J.E., (2001), Selling strategies: the effects of suggesting a decision structure to novice and expert buyers, Journal of the Academy of Marketing Science, vol. 29, no. 3, pp. 289-306;

Weitz, B.; Catleberry, S.; Tanner, J., (2007), Selling - Building Partnerships, McGraw-Hill Irwin, New York. 